\title{
WHAT IS APOPHATICISM? WAYS OF TALKING ABOUT AN INEFFABLE GOD
}

\author{
MICHAEL SCOTT \& GABRIEL CITRON
}

University of Manchester University of Toronto

\begin{abstract}
Apophaticism - the view that God is both indescribable and inconceivable - is one of the great medieval traditions of philosophical thought about God, but it is largely overlooked by analytic philosophers of religion. This paper attempts to rehabilitate apophaticism as a serious philosophical option. We provide a clear formulation of the position, examine what could appropriately be said and thought about God if apophaticism is true, and consider ways to address the charge that apophaticism is self-defeating. In so doing we draw on recent work in the philosophy of language, touching on issues such as the nature of negation, category mistakes, fictionalism, and reductionism.
\end{abstract}

Apophaticism presents a philosophical approach to God and God-talk that is fundamentally and intriguingly at odds with the one found in contemporary analytic philosophy of religion. In contrast with the mainstream 'cataphatic' focus on describing and analyzing God's nature and attributes, apophatic writings take God to elude description and conception. Apophaticism has received a raw deal from analytic philosophers of religion. ${ }^{1}$ The works of apophatic writers (or apophatics as we will call them) are largely overlooked, despite arguably constituting one of the great medieval traditions of philosophical thought on God, with a significant presence in all three Abrahamic religions. And when apophaticism is considered it is usually presented as a strawman, defeating itself by unwittingly conceiving of an ostensibly inconceivable God. ${ }^{2}$ We believe that apophaticism, given a proper airing, is a coherent

\footnotetext{
${ }^{1}$ By contrast, apophaticism has been very widely discussed by continental philosophers, for example in Jacques Derrida (1992) and Jean-Luc Marion (1995).

${ }^{2}$ See, for example, Alvin Plantinga (2000). By contrast, Jonathan Jacobs (2015) aims for a more sympathetic treatment of divine ineffability, but he ends up looking at a theory somewhat different to apophaticism.
} 
position, valuable both due to its radical contrast with mainstream analytic philosophy of religion, and due to the philosophically important questions which it raises about metaphysics and religious language. This paper aims to be a first step towards putting apophaticism forward as a serious position in contemporary analytic philosophy of religion.

We have two main objectives. The first is to give a clear formulation of apophaticism, and the second is to examine what can and what cannot appropriately be said and thought about God if apophaticism is true. In section 1 we clarify the concept of divine ineffability that is essential to apophaticism, and we introduce what we call the representation problem: how can we can say or think anything about God consistently with his being ineffable? The remainder of the paper is dedicated to assessing and developing various ways in which apophatics have responded to this problem. In section 2 we discuss the use of negative sentences to talk about God; in section 3 we consider fictionalist and reductionist responses. Finally, in section 4, we take stock of where this leaves the possibility of legitimate apophatic God-talk.

This is not, of course, a comprehensive treatment of the apophatic position: we will not consider all the permutations of the theory, nor will we get into the arguments in favour of the theory, and we will only focus on one (albeit the most prominent) objection to it: the representation problem. Our approach is historically informed - and, we hope, historically informative - but it is principally driven by two philosophical concerns: to characterize apophaticism as a position, and to set out what apophatics can say about God consistently with that position. We will therefore smooth over some points of historical and theological difference, and ignore certain historical and theological nuances in order to get at what we think is the most philosophically interesting and promising position (or range of positions) available.

\section{GOD'S INEFFABILITY \& THE REPRESENTATION PROBLEM}

Consider the following quotations about divine ineffability which are illustrative of classical and medieval apophaticism:

Philo of Alexandria ( $1^{\text {st }}$ century): " $[\mathrm{H}] \mathrm{e}$ who was conducted by wisdom ... discerns this fact, that God is at a distance from every creature, and that any comprehension of him is removed to a great distance from all human intellect ... God ... may not be named or spoken of, and ... is in every way incomprehensible." (2013, p. 371) 
Gregory of Nyssa ( $4^{\text {th }}$ century): 'The Divine Nature, whatever It may be in Itself, surpasses every mental concept. For It is altogether inaccessible to reasoning and conjecture, nor has there been found any human faculty capable of perceiving the incomprehensible; for we cannot devise a means of understanding inconceivable things.' (2007, p. 146)

Dionysius ( $5^{\text {th }}$ or $6^{\text {th }}$ century): 'It cannot be spoken of and it cannot be grasped by understanding ... Existing beings do not know it as it actually is and it does not know them as they are. There is no speaking of it, nor name nor knowledge of it. Darkness and light, error and truth - it is none of these. It is beyond assertion and denial.' (1954, p. 141)

Maximus the Confessor: 'God is one, without beginning, incomprehensible, possessing in his totality the full power of being, fully excluding the notion of time and quality in that he is inaccessible to all and not discernible by any being on the basis of any natural representation ... God can neither conceive nor be conceived but is beyond conception and being conceived.' (1985, pp. 129 \& 148)

Moses Maimonides ( $12^{\text {th }}$ century): ' $[\mathrm{W}] \mathrm{e}$ are only able to apprehend the fact that $\mathrm{He}$ is and cannot apprehend His quiddity. It is consequently impossible that He should have affirmative attributes ... in any respect.' (1963, p. 135)

Muhammad ibn al-Arabi (13 ${ }^{\text {th }}$ century): 'It cannot be known through logical proof ... nor can definition grasp it. For He - glory be to him - is not similar to anything, nor is anything similar to Him. So how should he who is similar to things know Him to whom nothing is similar and Who is similar to nothing?' (2005, p. 33)

Meister Eckhart (14 ${ }^{\text {th }}$ century): 'God is nameless, because no one can say anything or understand anything about him ... So if I say: 'God is good', that is not true... And if I say 'God is wise', that is not true ... If I say: 'God is a being', it is not true; he is a being transcending being and transcending nothingness.' (1981, p. 206)

In accordance with remarks such as these, the theological secondary literature on apophaticism usually takes its proponents to be committed to some combination of the following three propositions:

(1) We cannot know what God's nature is.

(2) We cannot successfully describe God's nature.

(3) We cannot successfully conceive of God's nature. 
Propositions (1), (2), and (3) are then often taken to be closely interrelated. For example, according to Henny Fiskå Hägg:

What is denied or negated, then, is the possibility both to know and to express the divine nature: God is both greater than, and different from, human knowledge and thought. It also follows that human language is incapable of expressing him. (2006, p. 1)

And Denys Turner, in his seminal theological work The Darkness of God, claims:

It follows from the unknowability of God that there is very little that can be said about God: or rather, since most theistic religions have a great number of things to say about God, what follows from the unknowability of God is that we can have very little idea of what all these things said about God mean. (2002, p. 20)

It is important to note, however, that there is a significant philosophical gulf between (1) on the one hand, and (2) and (3) on the other. Even if we cannot know that $p$, we may nonetheless be able to mentally or linguistically represent $p$. Contrary to Turner, something being unknowable does not thereby preclude successfully describing or conceiving of it. Something could be unknowable to us (e.g. the weather over London on Feb 1st in the year $23 \mathrm{CE}$ ), ${ }^{3}$ or to anyone (e.g. the colour of Sherlock Holmes' eyes), consistently with our being able to have thoughts, beliefs, and construct descriptions about it. Someone sympathetic to natural theology, who thought it possible to come up with a believable - and even true - description or conception of God's nature, might agree that we nonetheless cannot know that the description or conception is true or accurate. In contrast, if we cannot conceive of $p$, then we cannot even believe $p$, let alone know it. Similarly, albeit more contentiously, it seems that if we cannot linguistically represent $p$, we cannot know $p .^{4}(1)$, therefore, is a much more modest claim than

${ }^{3}$ We intend this as an example where the means for finding out the truth of the proposition has been irretrievably lost. It is, therefore, a limitation on our knowledge in principle rather than one that can be overcome by better evidence or further investigation.

${ }^{4}$ One issue here is whether thought requires symbolic representation. Jerry Fodor (1981), for instance, argues that thought takes place in an innate language; in thinking something, a thought is thereby linguistically formulated although the thinker may be unaware of the symbols and grammar of that language. If Fodor is right, then if something cannot be linguistically represented, it follows that it cannot be mentally represented either. 
the other two: (2) and (3) each appear to entail (1), but not vice versa. Given these considerations, it seems to us that (1) alone is not sufficient for apophaticism. Rather, it is propositions (2) and (3) which properly capture the radical objectives aimed at by apophatics. ${ }^{5}$

Having characterised apophaticism as consisting of (2) and (3) we must now ask how strong each of those denials is meant to be. One important consideration is that the restrictions on our thought and linguistic powers posited by (2) and (3) should be taken to be modal. That is, the limitations are ones that we are in principle unable to overcome, rather than contingent, practical limitations. Being unable to describe God because one has not acquired the relevant linguistic skills, or being unable to think of God because one happens to lack the requisite conceptual sophistication, is not sufficient for (2) or (3) as intended by the apophatics. Apophaticism is not taken to be true by virtue of contingent facts about our circumstances and abilities limitations are not 'merely medical', as Bertrand Russell might have put it (1936, p. 143). Rather, we take (2) and (3) to be saying that there is no extension of our linguistic or intellectual powers that could put us in a position to be able to successfully describe or conceive of God.

If we take the core apophatic claim as being an in principle limitation on the describability and conceivability God's nature, this raises the further question of what class of beings this limitation applies to. Does it, for example, apply only to humans or is it a limitation on describability and conceivability tout court? Helpfully, a number of apophatic authors discuss the ideas of God that are possessed by angels. In addition to being better informed than us, angels are usually presented as both morally and intellectually superior to humans. ${ }^{6}$ The conceptions and descriptions that angels have of God are taken to be as good as it is possible for any

\footnotetext{
${ }^{5}$ Medieval apophatics are not always careful in distinguishing between knowing about God and conceiving of him, and thus sometimes talk of our inability to know God when the context makes clear that they have the more radical claim of God's inconceivability in mind. The Cloud of Unknowing, for example, says that "all rational beings ... have in them ... a faculty of knowledge, and ... a faculty of love; and God, their maker, is forever beyond the reach of the first of these, the intellectual faculty; but by means of the second, the loving faculty, he can be fully grasped by each individual being" (2001, p. 23). The author thereby conflates the faculty of knowledge with the intellectual faculty, and therefore sometimes expresses the fact that we cannot intellectually grasp or conceive of God by saying that we cannot know him.

${ }^{6}$ See, for example, Aquinas 2006, p. 121.
} 
created being to possess. However, while apophatics often take angels to make judgements about God that are better (in certain respects) than human ones, ${ }^{7}$ most apophatics (including the authors cited earlier) take all creatures including angels to be unable to successfully describe or conceive of God. It is this more thoroughgoing version of apophaticism that we will be focussing on, i.e. that there is no extension of our descriptive powers or our conceptual capacities that would allow for the representation of what God is like.

Matters become more complicated, however, when we consider whether apophatics think that even God can conceive of himself. John Scotus Eriugena answers clearly in the negative: 'How, therefore, can the Divine Nature understand of itself what it is, seeing that it is nothing? ... God does not know of Himself what $\mathrm{He}$ is because $\mathrm{He}$ is not a 'what', being in everything incomprehensible both to Himself and to every intellect.' (1987, pp. 192-6) Many apophatics, however, seem to dissent from this view. Nicholas of Cusa, for example, writes that: 'God is unknowable either in this world or in the world to come, for in this respect every creature is darkness, which cannot comprehend infinite light, but God is known to God alone.' (1997, pp. 126-7) If God is taken to be an ideal conceiver, surpassing even angels, then (2) and (3) are restrictions on the powers of only created beings rather than limitations on describability and conceivability per se. We should not, however, jump to the conclusion that there are two strengths of apophaticism in play. For those authors who say that God understands himself tend to qualify this by adding that God's understanding is qualitatively different to our own. According to Cusa, for instance, God is only incomprehensibly understandable' (1997, p. 92). Thus God's 'conceiving' is not an extension of creaturely conceiving, but a different category of thing altogether. In whatever sense God can conceive of or describe himself, then, it is not in our sense of 'conceive' or 'describe'. We therefore take it that paradigmatic apophaticism does not understand (2) and (3) merely relatively, but in terms of God's indescribability and inconceivability tout court. ${ }^{8}$

7 The judgements need not be representationally more accurate. For instance, angelic thought about God may satisfy superior moral standards to human thought.

${ }^{8}$ It is worth noting that some apophatics take God's indescribability and inconceivability to be grounded in the metaphysical claim that God has no nature at all, or rather, is beyond the having of any nature - as can be seen from the above quotation from Eriugena. In some cases, then, this could be considered a third core element of apophaticism, but we will not deal with it here. 
Having characterised apophaticism as requiring (2) and (3), and having clarified how strongly these conditions are taken, how can apophatics consistently engage in discourse about God? This is the 'representation problem. (2) and (3) claim that God cannot be represented either linguistically or conceptually, so apophatics have to be able to account for how they can engage in God-talk without representing God. A special case of this problem is, of course, how (2) and (3) can themselves be believed without self-defeatingly representing God.

Given the difficulty of the representation problem some apophatics go so far as to hint at an eliminativist response. Indeed, apophatic thinking is often presented as a process of progressively rejecting more and more subtle representations of God, requiring both intellectual and moral discipline, portrayed metaphorically as a steep ascent up a mountain. The summit, according to some apophatics, is a relationship with God characterised by ceasing to speak about God altogether. Thus Dionysius writes: 'language falters, and when it has passed up and beyond the ascent, it will turn silent completely' (Dionysius 1987, p. 239); and Gregory of Nazianzus: 'let every soul ... reverence in silence only the truth of the Divine Essence (which is) ineffable' (quoted in Eriugena 1987, p.193). However, even those apophatics who sometimes gesture towards silence as an ideal, do not themselves seem to do away with all talk about God? It therefore remains both relevant and pressing to ask: to what extent is continued engagement in religious thought and discourse about God available to apophatics? Answering this question will be the focus of the rest of this paper.

\section{TALKING NEGATIVELY}

The response to the representation objection that is most commonly associated with apophatics is that of the via negativa - a preference for saying what God is not rather than what God is. This approach uses the linguistic device of apophasis, which in this context involves speaking of God in sentences that either negate a predicate ascribed to God of the form

(4) God is not $p$.

${ }^{9}$ Of course, those apophatics most committed to the ideal of silence would be the least likely to have left us books on the subject. 
or else use a privative term

(5) God is not- $p$.

typically by constructing an affixal negation (in-, un-, -less) from a predicate expression. For convenience we will call sentences of either of these types negative sentences about God.

Negative sentences about God are used extensively by apophatics. The following are some illustrative quotations:

Dionysius: 'It is not a material body, and hence has neither shape nor form, quality, quantity, or weight. It is not in any place and can neither be seen nor be touched. It is neither perceived nor is it perceptible. It suffers neither disorder nor disturbance and is overwhelmed by no earthly passion.' (1987, pp. 140-1).

Dionysius: 'It cannot be spoken of and it cannot be grasped by understanding. It is not number or order, greatness or smallness, equality or inequality, similarity or dissimilarity. It is not immovable, moving, or at rest. ... It falls neither within the predicate of nonbeing nor of being.' $(1987, \text { p. } 141)^{10}$

Meister Eckhart: 'God is neither good nor better nor best of all.' (1981, p. 257)

Nicholas of Cusa: 'God is neither nothing nor something.' (1997, p. 212)

John Scotus Eriugena: 'For properly speaking there is in Him neither rest nor motion.' (1987, p. 39)

According to Dionysius, 'the way of negation appears to be more suitable to the realm of the divine' (p. 150). Eckhart paraphrases Dionyisus approvingly: 'negations about God are true but affirmations are unsuitable' (1986, p. 70). And Ibn Șaddiq endorses the claim that 'It is more correct to reject assertions concerning God than to ascribe anything positive to Him' (2003, p. 122 $2^{11}$ ). However, on the face of it, negative sentences about God represent God. So if God cannot be linguistically represented then it seems that there will be no advantage (at least with respect to their being true) in using negative sentences in preference to positive ones.

${ }^{10}$ Although Dionysius in some cases denies the identification of God with a property, he makes clear that he also intends to deny that God has these properties. For instance, God is not equality and also lacks the property of equality.

${ }^{11}$ This idea is mistakenly attributed to Aristotle by a number of the Jewish medievals (see also, for example, Ibn Pakuda, 2004, p. 134). 


\subsection{Some important distinctions: contradictions, contraries, and subcontraries}

To get a clearer idea of what apophatics are doing, it is useful to introduce a distinction, given its clearest early articulation by Aristotle, ${ }^{12}$ between two sorts of sentence negations: contradictions and contraries. Contradictory sentences are governed by two principles. First, a sentence and its contradictory cannot both be true (the law of contradiction). Second, they cannot both be false (the law of excluded middle). For instance,

6a. God is omnipotent.

$6 \mathrm{~b}$. It is not the case that God is omnipotent.

are contradictory sentences because they cannot both be true and cannot both be false. Contrary statements, however, are governed by the law of contradiction but not by the law of excluded middle. So while they cannot be jointly true, it is possible for both of them to be false. There are two classes of sentence denials that Aristotle considers that generate contraries rather than contradictories: sentences with non-referring subject expressions and category mistakes. For instance,

7a. The president of England is happy.

7b. The president of England is unhappy.

cannot be true together. However, according to the Aristotelian account, because the president of England does not exist, they are both false. In the following sentences

8a. Red is happy.

8b. Red is unhappy.

the predicate seems to be of the wrong category to describe the subject. They cannot both be true but they are, according to the Aristotelian account, both false. So negations of sentences that make category mistakes, along with negations of sentences with non-referring subjects, can generate contraries. We should note that the status of sentences with vacuous subjects and sentences involving category mistakes are philosophically contentious. For instance, while some agree with Aristotle that category mistakes are false, others, notably Russell (1908), regard them as literally senseless, while Martin (1975) and Thomason

${ }^{12}$ We will modify Aristotle's treatment to use proposition rather than term logic. 
(1972) take them to be meaningful but neither true nor false. We will return to these options later.

So Aristotle presents us with two ways of negating 'God is p'. There is the case - most simply expressed by (4) - where a sentence denies that the predicate $\mathrm{p}$ applies to God, yielding a contradictory sentence. There is the case - most simply expressed by (5) - where a predicate incompatible with $\mathrm{p}$ is assigned to God (typically one that incorporates a negative component into the predicate expression), yielding a contrary sentence. Given the differences in the logical behaviour of contradictions and contraries, a degree of caution is needed in distinguishing between the superficially similar ways of denying 'God is $p$ ' given by (4) and (5). ${ }^{13}$

One further distinction is needed. The negation of contrary sentences

$8 \mathrm{a}^{\star}$. Red is not happy.

$8 \mathrm{~b}^{*}$. Red is not unhappy.

yield subcontraries, which behave in a similar way to contraries except that subcontraries cannot both be false but they can both be true.

The contrary/subcontrary distinction is useful in the following way. In the quotations above and more generally, apophatics are not using negation to contradict sentences about God but, at least in many cases, provide subcontrary pairs or sequences of sentences. For instance, if

9a. God is not being.

9b. God is not non-being.

and

10a. God is not something.

10b. God is not nothing.

involve either category mistakes or are non-referring then, following the Aristotelian account, each pair will be jointly true. That is, they will be

${ }^{13}$ Although their approaches are in other respects very different, we find a comparable contrast in Russell's distinction between internal and external negation. According to Russell, we can interpret 'The president of England is not happy' in two ways. It could be saying that there is a unique entity that is the president of England who is not happy. In this case the negation is internal to the proposition and has narrow scope, operating on just the predicate expression. This is a contrary to (7a). Alternatively, it might be interpreted as saying that it is not the case that there is a unique entity that is both the president of England and happy. In this case, the negation is external to the proposition and the whole description falls within its scope. This contradicts (7a). 
subcontraries rather than contradictories. Now, not all of the negative sentences are combined with denials. For example, Dionysius says both

11a. God is not great.

11b. God is not small.

but 'great' is not the term negation of 'small', since an entity might, for instance, have some intermediate magnitude that is neither great nor small. Whether or not this is a mistake, it seems clear from the context that Dionysius is not trying to suggest by this example that God has intermediate magnitude. Presumably he would have no objection to saying

$11 b^{*}$. God is not small and has no intermediate magnitude. to generate the subcontrary.

Apophatics, therefore, do not in general appear to be affirming contradictory sentences about God. Instead, they are presenting contrary or subcontrary sentences. With these distinctions in place, we will return to the representation problem.

\subsection{The representation problem as applied to negative sentences about God}

Why might negative sentences about God be preferable to positive ones for an apophatic? As a starting point, let us consider whether there is some systematic difference between what is said by positive and negative sentences about God. There is a long history stretching back to Parmenides and Plato for the view that there an asymmetry between positive and negative sentences, with negative sentences in some way secondary to their positive counterparts. Notably Aquinas takes this view. He proposes that positive sentences signify the ontologically more basic fact of having rather than lacking something, they are epistemologically more basic by signifying composition rather than division, and they have a logical priority. 'With respect to vocal sound, affirmative enunciation is prior to the negative because it is simpler, for the negative enunciation adds a negative particle to the affirmative.' (1962, p. 65) Many apophatics followed this line of thinking. Thus, for example, according to Eckhart, 'privation necessarily follows possession, and negation is based on affirmation' (1986, p. 181), although he does not elaborate further. However, none of these points appear to show that negative sentences are better suited than positive ones for allowing apophatics to consistently talk about an indescribable and inconceivable God. Nor do apophatics 
tend to explicitly justify the use of negative sentences with any sustained defence of asymmetricalism. Indeed, Gregory of Nyssa rejects it outright:

To say that God has no evil in him is the same as calling him good, to confess him as immortal is to say that he lives for ever. We perceive no difference of meaning between these, but mean the same thing by each expression, even though one appears to express a positive thing, the other a negative. (2007, p. 88)

Gregory's first example is unsuccessful - 'not evil' is not equivalent to 'good' since it could also include the state of being neither evil nor good. ${ }^{14}$ But his observation that a syntactically negative sentence may express the same thought as a positive one is well taken and presents a problem for asymmetricalism. As Gregory says: 'while the form of the name changes, the devout understanding of the Subject remains consistent.' (2007, p. 88)

Even if there is not a systematic difference in the content of negative sentences as compared to positive ones, are they nonetheless less informative than their positive corollaries? In saying that God is not $p$, one rejects the positive counterpart - one excludes God's being $p$ - without specifying what the alternative involves. For example, in asserting

12. God does not have a material body.

it seems that the speaker is not thereby committed to a particular account of what God must be like to lack this property; all that it says is that this is not what God is like.

To the extent that negative sentences about God are less specific about God's nature, then they depend on less specific metaphysical commitments. One reason for using negative sentences, therefore, could be epistemological prudence. Because negative sentences are less informative about God, using negative sentences instead of positive ones reduces the chance of making a mistake. For someone wishing to avoid error in what they say about God, therefore, limiting oneself to negative statements about God looks like a useful tool. However, this is difficult to square with apophaticism. While Eckhart suggests (briefly, and without a defence) that negative sentences are entirely uninformative 'a negative statement provides no truth about the thing to which the

${ }^{14}$ This point was recognised by Plato $(2015,257 \mathrm{~B}-\mathrm{C})$ : calling something 'not great' does not pick out the opposite of what is great (i.e. what is small) any more than it does objects of an intermediary size. 
statement applies'. (1986 n. 178, p. 99) - negative sentences about God do still represent God as being some way or other. If God is not $p$, then God is such that he is not $p$. This may be less informative than a positive sentence about God but it is representational nonetheless. Notably, Maimonides recognises that negative sentences, like positive ones, 'bring about some particularization even if the particularization due to them only exists in the exclusion of what has been negated from the sum total of things that we had thought of as not being negated.' (1963, pp. 134-5) $)^{15}$ Writing around eight centuries later, A. J. Ayer makes a similar point: 'Why should it not be allowed that the statement that the Atlantic Ocean is not blue is as much a description of the Atlantic as the statement that the Mediterranean Sea is blue is a description of the Mediterranean? ... $[\mathrm{T}]$ o say that a description is relatively uninformative is not to say that it is not a description at all.' (1963, p. 47) The epistemic modesty motivation is suitable for someone who thinks that God is very difficult to describe or can be only partially described; it is not appropriate for someone who thinks that God is indescribable. There is no linguistic device, apophasis included, that can make the indescribable describable.

Neither epistemic prudence nor assymetricalism, therefore, look as if they will deliver an account of negative sentences consistent with (2) and (3). There are, however, two other options to consider.

\subsection{Metalinguistic negation}

One account of negation that has an already established place in the literature on apophaticism is presented by J. P. Williams

[Neoplatonist] apophasis is a second-order discourse, concerning not just the divine subject, but the discourse which addresses the divine: it generates no statements about God, but statements about theological language. (2000, p. 5)

Williams does not elaborate on how negative sentences that are apparently about God become directed towards religious language. We can, however, understand this account of negation as appealing to a commonplace use of negation - widely discussed in philosophical research on negation - to express an unwillingness to assert a given sentence or class of sentences,

${ }^{15}$ Though, as might be expected from an esotericist such as Maimonides, he also seems to state the opposite a few pages later: 'negation does not give knowledge in any respect of the true reality of the thing with regard to which the particular matter in question has been negated' (1963, p. 139). 
rather than to reject the truth of what is said. This is called metalinguistic negation. ${ }^{16}$ Negations of conditionals provide a particularly clear range of examples. For a conditional sentence with the form if $p$ then $q$, the negation of it is truth-conditionally equivalent to $p$ and not- $q$. That is,

13. $\sim(\mathrm{p} \rightarrow \mathrm{q}) \equiv \mathrm{p} \& \sim \mathrm{q}$.

However, if we take the conditional (14), it seems that someone who rejects it by asserting (15) need not agree with the conjunction in (16) even though it is truth-conditionally equivalent.

14. If John is given penicillin, he will get better.

15. It is not the case that if John is given penicillin, John will get better.

16. John will be given penicillin and John won't get better.

A plausible explanation of this is that the negation in (15) does not negate the proposition expressed by (14) but instead indicates a disagreement with the assertion of (14). As Grice explains, 'Sometimes the denial of a conditional has the effect of a refusal to assert the conditional in question' $(1989$, p. 81$)$. That is, the negation signals a refusal to assert (13) rather than an agreement with (15). As Michael Dummett puts it 'negation might be taken to be a means of expressing an unwillingness to assert 'A". (1973, pp. 328-30) Here are some other examples:

17. Ben Ward is not a black Police Commissioner but a Police

Commissioner who is black. (New York Times editorial, 8 January $1983)^{17}$

18. It's not possible that he will win, it is probable that he will win.

19. This is not a pair of pants, it is a pair of trousers.

As with the example of conditionals, negation in these cases is being used to disagree with the assertion of something rather than with the content of what is asserted. In (17), for instance, the negation is not being used to reject the fact that Ben Ward is black and is a Police Commissioner but rather to reject the priority implied by stating these facts in a particular order.

Returning to apophaticism, we can see that it is possible to interpret the negative sentences used by apophatics as employing metalinguistic negation to disagree with the assertion of positive sentences about God, rather than using 'ordinary' negation to say that God lacks

\footnotetext{
${ }^{16}$ The seminal treatment of this topic is Horn (1989), ch. 6.

17 Taken from Horn (1989, p. 371).
} 
a certain property. The metalinguistic approach has a couple of significant attractions. First, an apophatic can use metalinguistic negative sentences about God without thereby representing God as lacking a property and thereby falling foul of the representation problem. Rather, the apophatic is rejecting the appropriateness of sentences that represent God. On this account, what is communicated by $(9 a)$ is not that it is false that God is being but rather (with a bit of elaboration)

$9 b$. It is inappropriate to say that 'God is being'.

That is, the point of saying (9a) and other similar sentences is not to offer any insight into God's nature but instead to point up the limits of what we ought to say about God. Subcontraries are being used, on this account, to show that no sentence (negative or positive) is appropriate for representing God.

The second advantage is that metalinguistic negation allows for a consistent statement of the apophatic position itself. For instance, (2) appears problematic if understood as itself saying something about God since it appears both to linguistically represent God and to say that no such representation can be successful. However, understood metalinguistically as saying that it is inappropriate to use sentences that aim to successfully represent God, the position is not self-defeating. Metalinguistic negation, therefore, seems to provide a promising way of understanding the apophatic's position. ${ }^{18}$

Notwithstanding its theoretical advantages, however, the metalinguistic interpretation would make for a highly limited form of apophaticism. Rather than saying that representations of God have mistaken content, apophatics would only be making claims about the impropriety of the use religious language. Some apophatic writings appear sympathetic to a metalinguistic interpretation: according to Eriugena 'that which says: "It is not Truth", clearly understanding, as is right, that the Divine Nature is incomprehensible and ineffable, does not deny that it is, but (denies) that it can properly be called Truth' (1987, p. 49). ${ }^{19}$ However, most apophatic authors, Eriugena included, repeatedly contend that various positive claims about God misrepresent God.

\footnotetext{
${ }^{18}$ The reason for the impropriety might be - for example - moral or spiritual; they could not, of course, be inappropriate because they are false.

${ }^{19}$ It is interesting to note that there is a group of contemporary descendants of apophaticism - Wittgensteinian philosophers of religion - who seem to embrace the idea that negative sentences about God are actually second-order remarks about what
} 
Indeed, most apophatics are committed to this misrepresentation claim by the arguments which they provide for accepting (2) and (3) in the first place. For example, arguments from God's absolute non-complexity which can be found across Jewish, Christian, and Muslim apophatics, are taken to entail that God actually is indescribable and inconceivable rather than just that it is inappropriate to talk about him in certain ways. ${ }^{20}$

A further problem for the metalinguistic interpretation - at least as a complete account of the apophatic use of negative sentences - is that apophatic writers who use apophasis claim that negative sentences about God are also unsatisfactory and must be rejected:

Dionysius: 'It is beyond assertion and denial. We make assertions and denials of what is next to it, but never of it, for it is both beyond every assertion, being the perfect and unique cause of all things, and, by virtue of its preeminently simple and absolute nature, free of every limitation, beyond every limitation; it is also beyond every denial.' (1987, p. 141)

Gregory Palamas: 'The excellence of Him Who surpasses all things is not only beyond all affirmation, but also beyond all negation; it exceeds all excellence that is attainable by the mind.' (1983, p. 57)

Abu Yaqub al-Sijistani: 'Whoever worships God by denying the attributes falls into a hidden anthropomorphism, just as someone who worships Him by affirming them falls into obvious anthropomorphism.' (Quoted in Walker 1993, p. 75)

While some of these comments might be interpreted as metalinguistic denials of metalinguistic denials, ${ }^{21}$ it seems more plausible to see them as rejecting positive and negative sentences because they both misrepresent God.

can and cannot be said about God. Consider, for example, Rush Rhees' remark:' "God is not an object." And this is a grammatical proposition.' (1997, p. 37)

${ }^{20}$ See, for example, Maimonides 1963, Pt I, chaps 51 \& 57; Maximus the Confessor, 1985, pp. 143-4; and the pseudepigraphic Muslim treatise Theology of Aristotle (quoted in Adamson, 2002, p. 112).

${ }^{21}$ The denials of negations are sometimes seen as irremediably inconsistent and Dionysius' thought has been called 'paradoxical and self-negating.' (Light 1998, pp. 205-6) These comments have also been seen as evidence for apophatics being supporters of dialetheism about religious language (see, for example, Priest 2002, pp. 22-3). Paraconsistent logic is a modification of classical logic that allows for the truth of contradictory sentences; dialetheists believe that some contradictory sentences are actually true. However, as we have noted, we do not find Dionysius saying things like 'God is not-being and God is not non-being'. Nor does he in general endorse contradictory sentences about God. 
Is there a different account of negative sentences that can avoid the representation objection while also employing a conventional notion of negation?

\subsection{Category mistakes}

We have already set the stage for a way of addressing this problem. As we saw in the earlier discussion of contraries and subcontraries, according to the Aristotelian account one of the ways in which subcontrary sentences could be true is if they involve a category mistake. This suggest the following interpretation of negative sentences about God. Suppose that apophatics take greatness, being, order, passion, similarity and any other predicate that we may consider, to be categorially inappropriate for God, i.e. as unsuited to God as happiness is to red. (9a) and (9b) are (on the Aristotelian account) true because, if being is not a category that applies to God then God is not being and God is also not non-being. Moreover, there is some basis for thinking that at least some apophatics saw claims about God as category mistakes. For instance, according to Maimonides

even those negations are not used with reference to or applied to Him, may He be exalted, except from the following point of view, which you know: one sometimes denies with reference to a thing something that cannot fittingly exist in it. Thus we say of a wall that it is not endowed with sight. (1963, p. 136, also quoted approvingly by Eckhart 1986, p. 100)

Do negative sentences about God, understood as the denial of category mistakes, avoid the representation problem? The answer to this will hinge on our account of category mistakes. Space precludes our giving a detailed explanation of this topic in this paper. However, even without a full treatment of the topic, we can see the kind of position on category mistakes that apophatics would need to defend. ${ }^{22}$

There are three main position on the status of sentences that commit category mistakes: they are (a) false, (b) lack a truth value, or (c) senseless. Suppose that category mistakes are false (a position defended by Magidor: 2013). So (4) and (5) will both be false. However, it follows that

20. It is not the case that God is $p$

21. It is not the case that God is not- $p$

${ }^{22}$ For a thorough review of the different theories of category mistakes see Ofra Magidor (2013). 
will both be true. As we noted in 3.2, while these negative claims might be less informative than positive ones, they still represent God. The error made in a category mistake is perhaps more serious than a mundane mistake since it betrays a misunderstanding about the essential nature of the thing being described. But learning of such an error is still informative: one finds out, in being told (10a) and (10b) that God does not fit into the same category as other things without being nothing either. If category mistakes are false, therefore, interpreting negative sentences as correcting category mistakes will run into the representation problem. We get to a similar conclusion if category mistakes are neither true nor false (a position adopted by Thomason (1972) and Martin (1975)). If (4) is neither true nor false then (20) will be true, yielding the same problem.

What if category mistakes are literally senseless? Bertrand Russell (1908) thought as much, as did Peter Strawson (1952, pp. 226-7). This also seems to be the most promising account of category mistakes for apophaticism, at least as a way of escaping the representation problem. Its key advantage is that if sentences about God's nature are senseless, then neither stating them nor negating them will represent God; for all these utterances will lack representational content. As such, the representation problem is avoided. There are, however, significant theoretical costs. First, despite its philosophical pedigree, there are serious objections to this account of category mistakes. One problem relates to the compositionality of language. Speakers of languages seem to have the potential to understand indefinitely many sentences, suggesting that the meanings of sentences are composed from the meanings of their parts and grasped by speakers grasping the meanings of constituent expressions. Since we understand the meanings of 'red' and 'happy', and since 'red is happy' appears to be grammatically felicitous, why should we deny that the category mistake is meaningful? Another problem is that 'God is great' and 'Dieu est grand' appear to be synonymous, but this could only be the case if they have the same meaning - entailing that neither is meaningless. ${ }^{23}$

The second cost to the meaningless theory is that it looks very much at odds with what apophatics say. While they say that representations of God are mistaken, that negative sentences about God are preferable to positive ones and often then that the negative sentences should themselves

${ }^{23}$ For discussion of these objections and a barrage of other problems see Magidor 2013: Ch. 3. 
be denied, they do not say that such talk is senseless. It is the inadequacy of meaningful language about God rather than the meaninglessness of such language that most often seems to be being proposed by apophatic writers.

Both category mistakes and metalinguistic negation, therefore, offer theoretical options to apophatics for interpreting negative sentences about God that do not commit the speaker to a position on what God is like. Neither option, however, appears to be endorsed by apophatic writers.

\section{TALKING POSITIVELY (OR SEEMING TO DO SO)}

Whatever the best interpretation of the apophatics' use of negative language about God, no apophatics we know of limit themselves to only negative sentences. In fact, many apophatics suggest a variety of surprising interpretations of positive sentences about God that neutralise their representational content, at least some of which are usually taken to be more characteristic of a more modern religious antirealism. We will look at two of the main proposals - though they are not the only ones - that we find scattered through a number of apophatic writings, namely fictionalism and reductionism.

\subsection{Fictionalism}

One way of making statements of the form 'God is $\Phi$ ' while avoiding the representation problem, is by granting that though these statements do say that God is $\Phi$, they can be used to do something other than to express the belief that God is $\Phi$, without any commitment to God's being $\Phi$. This would be a religious variety of fictionalism: the theory that we can legitimately - or even should - engage in a discourse without believing the claims of that discourse. Consider the following comments from Teresa of Avila:

O God, what must that soul be like when it is in this state! It would fain be all tongue, so that it might praise the Lord. It utters a thousand holy follies, striving ever to please Him Who thus possesses it. (2002, p. 97)

Teresa grants that when the religious person utters such praises as 'God is good' and 'God is wise' they are uttering follies, so she takes these utterances to be making the representational claims that God is 
good and that God is wise. The speaker, however, does not utter these sentences to express beliefs about God's nature, but rather, to please God by expressing love for him, which Teresa takes them to be doing by their revelling in God-talk. So without running into the representation problem, a speaker can employ sentences about God, because they are doing so for a purpose other than representing him or expressing beliefs about him.

Gregory of Nyssa suggests a different but still seemingly fictionalist interpretation of claims about God's nature and attitudes. According to Gregory, God 'eludes all attempt at comprehension' (2007, p. 62), and 'all men of sense reckon it is impossible for the ineffable nature to be expressed in the meaning of any words' (ibid, p. 72). Nonetheless, God is variously described in the Bible as rejoicing over his servants, being furious with sinners, being merciful, and the like. Gregory explains this as follows:

[T] he text informs us in every word of this kind, I believe, that the divine Providence deals with our feebleness by means of our own characteristics, so that those inclining to sin may restrain themselves from evils through fear of punishment, those convicted may not despair when they perceive the opportunity of gaining mercy by change of heart, and those who live rightly may by strictness of conduct take more delight in their virtues, as by their own way of life they give joy to the one who becomes the provider of good things. (ibid, p. 154)

Gregory thus seems to be suggesting that although talk of God's attitudes is strictly false (because it represents God), it can have the pragmatic function of encouraging people to be virtuous and discouraging them from sin. Who exactly are these false statements meant to encourage? Only the unsophisticated masses who do not realise their falsity, or everyone, including the apophatics who understand that they are false? It is not entirely clear from Gregory, though he seems to lean towards the latter option. We might wonder how the use of sentences expressing false beliefs - by people who do not believe them and know them to be false could possibly influence their behavior for the better, without tempting them to cross the line into belief (even if only intermittent). One answer, suggested by Richard Joyce's fictionalist treatment of ethics (2001), is that by pretending that these sentences are true - by imaginatively engaging in God-talk as one might immerse oneself in a fiction - one can effect 
a morally advantageous regulative influence on one's practical thinking and decision making. ${ }^{24}$

Thus Gregory suggests ways of using sentences about God - to express love for God or to encourage moral behaviour - without being committed to their truth or to the belief that God can be represented. It is worth pausing for a moment to consider just how surprising it is to find these positions articulated by medieval philosophical theologians. Fictionalism is generally seen as a modern philosophical theory, and in the philosophy of religion it is usually discussed as a contentious way of responding to atheism. Here we can see that religious fictionalism can serve a different purpose. Rather than legitimizing atheistic engagement in religious discourse and practice for its instrumental value, fictionalism can provide a positive account of the merits of continuing to say and think positive things about God for apophatics who do not deny that there is a God but who find no representation of God's nature to be true.

While fictionalist God-talk avoids the representation problem, there are limits to its usefulness for apophaticism. Specifically, apophatics cannot be fictionalists about (2) and (3) in a way that would help them unless they disbelieve apophaticism! We are therefore still faced with the problem of how apophatics can claim (2) and (3) without falling foul of the representation problem. Fictionalism therefore offers apophatics only a partial solution.

\subsection{Reductionism}

Another way to engage in religious discourse while avoiding the representation problem is by committing to a reductive account of the meaning of God-talk. The reductive strategy is to find a reduced class of statements (in this case ones which are compatible with apophaticism) that give the truth-conditions for statements that seem, on their face, to be about something which is taken to be philosophically contentious (in this case, representations of God). There are at least three different

${ }^{24}$ Other apophatics - such as Maimonides - have seen false representational beliefs about God's benevolence and justice as being of instrumental moral value not to the apophatics who know that they are false, but rather, only to the unsophisticated masses who do not know that they are false (and who are not able to follow the arguments of the apophatics). As he says, some beliefs expressed in the Bible are "only the means of securing the removal of injustice, or the acquisition of good morals" such as "the belief that God is angry with those who oppress their fellow-men ... or the belief that God hears the crying of the oppressed and vexed." (1904, p. 315) 
proposals made by apophatics for what the reduced class might be, namely: (a) negative statements about God, (b) statements about God's actions, and (c) statements about the world. In each of these cases what seem to be positive statements about God's nature, turn out actually to be about something else: about what God is not like (rather than what he is like), about what God does (rather than what he is), or about the world (rather than God).

Because we have already discussed negative statements about God, and because reductions to statements about the world seem to be quite rare, we will focus here on reductions to statements about God's actions. Gregory of Nyssa seems to suggest an idea along these lines in the following passage:

"[T]he nature of him who Is is ineffable; but he gets his titles from the actions he is believed to perform for our lives ... That this is so, is clearly confirmed by divine scripture through great David, who refers to the divine Nature as it were by special and apt names which are suggested to him by the divine action: 'Pitiful', he says, 'and merciful is the Lord, patient and rich in mercies.' [Ps. 103:8] What do these words mean? Do they refer to action or to nature? Everyone will agree, it can only be to the action." (2007, pp. 91-2)

The general idea expressed here is spelled out in somewhat more detail by Maimonides, who offers an example of this kind of reductive account for apparently positive descriptions of God:

"Whenever any one of His actions is perceived by us, we ascribe to God that emotion which is the source of the act when performed by ourselves, and call Him by an epithet which is formed from the verb expressing that emotion. We see, e.g., how well He provides for the life of the embryo of living beings; how He endows with certain faculties both the embryo itself and those who have to rear it after its birth, in order that it may be protected from death and destruction, guarded against all harm, and assisted in the performance of all that is required [for its development]. Similar acts, when performed by us, are due to a certain emotion and tenderness called mercy and pity. God is, therefore, said to be merciful ..." (1904, p. 76)

Thus, positive sentences of the form 'God is $\Phi$ ' are reduced to sentences of the form 'God performed action $\Psi$ ', where $\Phi$ is the quality that we would usually attribute to a human agent if that agent were to perform action $\Psi$. It follows that 'God is $\Phi$ ' is not made true by a fact about God's 
nature but by a fact about his actions.

Religious reductionism has a longer pedigree than fictionalism, ${ }^{25}$ though despite this it is rarely acknowledged by analytic philosophers of religion to have a place in the works of important philosophicaltheologians in the Judaeo-Christian tradition.

One challenge levelled at religious reductionists is why they should continue to speak the way that they do, rather than simply using the reduced class of sentences. That is, if the truth-conditions of apophatics' sentences about God's nature are determined by God's actions rather than his nature, why do apophatics not simply speak explicitly about God's actions rather than continuing to talk in terms of God's nature? Why do apophatics insist on talking in such a misleading manner? One justification that apophatics could give for preferring to talk in terms of God's nature, could parallel the pragmatic considerations we saw underlying Gregory of Nyssa's fictionalism (in sec 3.1). That is, reductionist apophatics might consider it to be morally beneficial that actional facts are expressed by means of sentences whose face-value sense is that of standard representational claims about God, because using sentences which engage in a face-value story about a God who is just and merciful - even without committing to the truth of such claims when interpreted at face-value - might help spur its users to greater morality. ${ }^{26}$

Even if the reduction of apparently positive God-talk to statements about God's actions is successful as a reductive theory, it must still be asked whether or not it avoids the representation objection. One problem is that acting involves an agent and it is not clear whether it is possible for what is indescribable and inconceivable to be an agent. One radical response to this concern is to avoid it by reducing sentences about God to statements about natural occurrences in the world rather than to statements about God's actions. In this way apparently representative statements about God have truth conditions which do not involve God at all, and therefore completely avoid the representation problem. It is possible that Maimonides suggests a move like this, ${ }^{27}$ but it does not seem to be a common one.

\footnotetext{
${ }^{25}$ See Scott 2013, chaps 9 \& 14 .

${ }^{26}$ There are, of course, many other objections to religious reductionism. For an overview see Scott 2013, pp. 120-3.

27 See his 1904, Part I, chap 56.
} 
As with the fictionalist proposal, however, it seems that reduction to actions will not be able to account for (2) and (3) themselves. Most fundamentally because it is the non-reduced truth of those statements that motivates a reductionist interpretation of other God-talk in the first place. But also because it is far from clear what statements about God's actions (2) or (3) could plausibly be reduced to. So - as we found with fictionalism - reductionism offers at best a limited response to the representation problem.

\section{CONCLUSION: THE APOPHATIC PROCESS}

Where does all this leave the apophatic with regard to God-talk that avoids the representation problem? We have seen that fictionalism avoids the representation problem in most cases, but that it falls down when it comes to the special cases of (2) and (3) themselves. To patch this problem, could apophatics mix-and-match strategies? For example, perhaps the metalinguistic interpretation could be applied specifically to (2) and (3) so they are understood as statements about the propriety of representational talk about God, rather than as self-defeating statements about God's indescribable and inconceivable nature. Thus, in saying (2), for example, one would be communicating that it is inappropriate to try to describe God. The problem here, as we noted earlier, is that the merely metalinguistic interpretation of (2) and (3) seems to undermine the reasons that apophatics have to endorse apophaticism in the first place. For most apophatics, their position is motivated by the concern that representations of God fail in a systematic way: they are not merely inappropriate, they are in error. How can they say this, though, without undermining their own position?

There is, however, a different way of bringing together apophatic concerns about the truth of representations of God with a metalinguistic reading of (2) and (3). Suppose that apophaticism begins as a process of religious engagement and refinement in which successive attempts to represent God's nature, however sophisticated they may be, are each found to be inadequate. ${ }^{28}$ Apophatics, engaged in this process, progressively reject each representation of God that they consider. Now, when the apophatic considers

\footnotetext{
${ }^{28}$ For a more detailed discussion of this process see Scott (2013): the 'Cartesian' option discussed in Chapter 2 offers another way to escape the representation problem.
} 
22. We can successfully describe God's nature

23. We can successfully conceive of God's nature

what are they to conclude? If they say that (22) and (23) are false then (given certain assumptions about what it is to describe or conceive of God's nature) then the claims will be true, leading to a self-defeating position. However, given that they take there to be such widespread error in any representation of God that is not self-defeating, (22) and (23) are inappropriate things to say and could reasonably be denied metalinguistically. On this account, it is because (22) and (23) is among the very few sentences about God that cannot be false that (22) and (23) should be metalinguistically denied. This radical account of divine ineffability, therefore, is not hoist by its own petard. Of course, whether the medieval apophatics would take this particular mix-and-match solution to accurately capture their own positions, or whether they would be willing to embrace it in order to avoid the representation problem, is another matter.

\section{BIBLIOGRAPHY}

Adamson, Peter. 2002. The Arabic Plotinus: A Philosophical Study of the Theology of Aristotle. London: Duckworth.

Aquinas. 1962. Aristotle on Interpretation: Commentary by St. Thomas \& Cajetan tr. Jean T. Oesterle. Marquette University Press.

Aquinas. 2006. Summa Theologiae, Questions on God. Ed. Brian Davies and Brian Leftow. Cambridge University Press.

Ayer, A. J. 1963. 'Negation' in Philosophical Essays. London: Macmillan.

Cusa, Nicholas. 1997. Nicholas of Cusa - Selected Spiritual Writings. Tr. H. Lawrence Bond. New Jersey: Paulist Press.

Derrida, Jacques. 1992. 'How To Avoid Speaking: Denials', tr. Ken Frieden. In Derrida and Negative Theology. Eds. Harold Coward and Toby Foshay. Albany: State University of New York Press.

Dionysius. 1987. The Mystical Theology, in his Pseudo-Dionysius: The Complete Works, trans. Colm Luibheid \& Paul Rorem. New Jersey: Paulist Press.

Dummett, Michael. 1973. Frege: Philosophy of Language. London: Duckworth. Eckhart, Meister. 1981. Meister Eckhart - The Essential Sermons, Commentaries, Treatises, and Defense. Tr. Edmund College and Bernard McGinn. New Jersey: Paulist Press.

Eckhart, Meister. 1986. Meister Eckhart - Teacher and Preacher ed. Bernard McGinn with the collaboration of Frank Tobin and Elvira Borgstadt. New Jersey: Paulist Press. 
Eriugena. 1987. Periphyseon (Division of Nature) tr. I. P. Sheldon-Williams, revised by John O’Meara. Montreal: Ballarmin.

Fodor, Jerry. 1983. The Modularity of Mind. Cambridge, Mass.: MIT Press.

Gregory of Nyssa. 1954. St Gregory of Nyssa: The Lord's Prayer, The Beatitudes tr. Hilda C. Graef, eds. Johannes Quasten and Joseph Plumpe. New York: Paulist Press.

Gregory of Nyssa. 2007. Gregory of Nyssa: Contra Eunomium II eds. Lenka Karfíková, Scot Douglass and Johannes Zachhuber. Leiden, Boston: Brill.

Hägg, Henny Fiskå. 2006. Clement of Alexandria and the Beginnings of Christian Apophaticism. Oxford: Oxford University Press.

Horn, Laurence R. 1989. A Natural History of Negation. Chicago: University of Chicago Press.

Muhammad ibn al-Arabi. 2005. The Meccan Revelations, vol I, ed. Michel Chodkiewicz. New York: Pir Press.

Ibn Pakuda, Bahya ben Joseph. 2004. The Book of Direction to the Duties of the Heart, trans Menahem Mansoor, Sara Arenson, \& Shoshana Dannhauser, Oxford, The Littman Library of Jewish Civilization

Ibn Șaddiq, Joseph. 2003. The Microcosm of Joseph Ibn Șaddiq, trans Jacob Haberman, Madison, Fairleigh Dickinson University Press.

Jacobs, Jonathan D. 2015. 'The Ineffable, Inconceivable, and Incomprehensible God: Fundamentality and Apophatic Theology', Oxford Studies in Philosophy of Religion, 2015

Joyce, Richard. 2001. The Myth of Morality. Cambridge: Cambridge University Press.

Light, Aimee. 1998. 'Sculpting God: An Exchange (1)' Harvard Theological Review 91: 2.

Magidor, Ofra. 2013. Category Mistakes. Oxford: Oxford University Press.

Maimonides, Moses. 1904. The Guide for the Perplexed, trans. M Friedländer, London, Routledge \& Kegan Paul

Maimonides, Moses. 1963. The Guide of the Perplexed vol one tr. Shlomo Pines. London: The University of Chicago Press.

Marion, Jean-Luc. 1995. God without Being. Tr T Carlson. Chicago: Chicago University Press.

Martin, J. 1975. 'A many valued semantics for category mistakes', Synthese 31: 63-83.

Maximus the Confessor. 1985. Maximus Confessor - Selected Writings. Tr George C. Berthold. New Jersey: Paulist Press.

Palamas, Gregory. 1983. Gregory Palamas: The Triads. Ed. John Meyendorff, tr. Nicholas Gendle. New Jersey: Paulist Press.

Philo of Alexandria. 2013. The Works of Philo: Complete and Unabridged (New Updated Edition). Tr CD Yonge. USA: Hendrickson Publishers. 
Plato. Plato: Theatetus and Sophist (Cambridge Texts in the History of Philosophy). Ed. Christopher Rowe. Cambridge Universty Press.

Priest, Graham. 2002. Beyond the Limits of Thought. Oxford: Clarendon Press. Rhees, Rush. 1997. Rush Rhees on Religion and Philosophy, eds. DZ Phillips \& Mario von der Ruhr, Cambridge, Cambridge University Press.

Russell, Bertrand. 1908. 'Mathematical Logic as Based on the Theory of Types' American Journal of Mathematics 30: 3, pp. 222-262.

Russell, Bertrand. 1936. 'The Limits of Empiricism' Proceedings of the Aristotelian Society 131.

Scott, Michael. 2013. Religious Language. Basingstoke: Palgrave Macmillan. Strawson, Peter. 1952. Introduction to Logical Theory. London: Methuen.

Teresa of Avila, The Life of the Holy Mother Teresa of Jesus (The Complete Works:

St Teresa of Avila, Vol. I), trans. E Allison Peers, Burns \& Oates, London, 2002

Thomason, R. (1972): 'A semantic theory of sortal incorrectness', Journal of Philosophical Logic 1: 209-58.

Turner, Denys. 2002. The Darkness of God: Negativity in Christian Mysticism. Cambridge: Cambridge University Press.

Walker, Paul E. Early Philosophical Shiism: The Isma'ili Neoplatonism of Abu Ya'qub al-Sijistani, Cambridge University Press.

Williams, J. P. 2000. Denying Divinity. Oxford: Oxford University Press. 